\title{
URGENSI PEMBELAJARAN BERBASIS KEARIFAN LOKAL
}

\author{
Nadlir \\ (Dosen PGMI UIN Sunan Ampel)
}

\begin{abstract}
Abstrak:
Tulisan ini mengurai pentingnya pembelajaran berbasis kearifan lokal di dalam dunia pendidikan. Pembelajaran di lembaga pendidikan terdiri atas berbagai materi ajar (subject matter), dimana setiap materi tersebut sudah ditentukan target-target pembelajarannya. Tanpa mengganggu sama sekali setiap materi ajar tersebut, bahkan memperkuatnya, muatan kearifan lokal perlu dimasukkan. Apapun yang diterima peserta didik merupakan sebuah materi ajar, baik berupa teori, praktik, contoh-contoh soal maupun sikap pendidik itu sendiri. Menggambarkan secara jelas kekhasan materi ajar, ruang kelas, lingkungan pendidikan maupun buku-buku/ media pendidikan menjadi sebuah kebutuhan lembaga pendidikan agar dapat diterima efektif oleh peserta didik. Pengintegrasian akan efektif jika muatan kearifan lokal dapat masuk menjadi materi ajar pokok yang tidak sekedar asal dapat ditempelkan. Dalam Pendidikan Agama, misalnya, perlu dapat menjelaskan hukumnya berwirausaha, berbisnis, belajar, bercocok tanam, memanfaatkan lahan kosong di bawah tegakan tanaman, mengolah makanan secara alami tanpa pewarna maupun pengawet buatan, mensyukuri kekayaan hayati, dan lain-lain. Di dalam PKn perlu untuk menjelaskan posisi negara yang penuh hutang, perlunya membangun kemandirian ekonomi, perlunya mencintai hasil produksi dalam negeri maupun praduk lokal dan lain-lain. Materi ajar Bahasa Indonesia dapat mengarahkan kesadaran anak tentang kearifan lokal melalui pelajaran mengarang,
\end{abstract}


Nadlir

membuat puisi ataupun membuat peribahasa dengan tematema lokal. Demikian pula pada IPA, IPS, Seni Budaya dan Ketrampilan, Pendidikan kesehatan, berbagai materi ajar dasar maupun pengembangan diri.

Kata Kunci: Pembelajaran dan Kearifan Lokal

\section{A. Pendahuluan}

Derasnya arus globalisasi, modernisasi dan ketatnya puritanisme dikhawatirkan dapat mengakibatkan terkikisnya rasa kecintaan terhadap kebudayaan lokal. Sehingga kebudayaan lokal yang merupakan warisan leluhur terinjakinjak oleh budaya asing, tereliminasi di kandangnya sendiri dan terlupakan oleh para pewarisnya, bahkan banyak pemuda yang tak mengenali budaya daerahnya sendiri. Mereka cenderung lebih bangga dengan karya-karya asing, dan gaya hidup yang kebarat-baratan dibandingkan dengan kebudayaan lokal di daerah mereka sendiri. Slogan "aku cinta produk lokal, aku cinta buatan Indonesia" sepertinya hanya menjadi ucapan belaka, tanpa ada aplikasi nyata yang mendukung pernyataan tersebut.

Penggunaan bahasa asing di media massa dan media elektronik bukan tidak mungkin menyebabkan kecintaan pada nilai budaya lokal perlahan memudar. Padahal, bahasa sebagai alat dalam menyampaikan pembelajaran sangat besar pengaruhnya terhadap pembentukan karakter pemuda. Tidak ada lagi tradisi yang seharusnya terwariskan dari generasi sebelumnya. Modernisasi mengikis budaya lokal menjadi 
kebarat-baratan, sedangkan puritanisme sering menganggap budaya sebagai praktik sinkretis yang harus dihindari. ${ }^{1}$

Kebudayaan lokal merupakan kebudayaan yang sangat dijunjung tinggi oleh masyarakat adat. Namun yang terjadi pada pemuda sangat berbeda dengan apa yang kita pahami tentang kebudayaan lokal, bahkan kebudayaan itu sudah terkikis dan tergantikan oleh budaya asing yang sama sekali tidak dipahami.

Agar eksistensi budaya tetap kukuh, maka kepada generasi penerus dan pelurus perjuangan bangsa perlu ditanamkan rasa cinta akan kebudayaan lokal khususnya di daerah. Salah satu cara yang dapat ditempuh di sekolah adalah dengan cara mengintegrasikan nilai-nilai kearifan budaya lokal dalam proses pembelajaran, ekstra kurikuler, atau kegiatan kesiswaan di sekolah. Misalnya, dengan mengaplikasikan secara optimal Pendidikan Berbasis Kearifan Budaya Lokal. Kearifan lokal merupakan akumulasi dari pengetahuan dan kebijakan yang tumbuh dan berkembang dalam sebuah komunitas yang merepresentasikan perspektif teologis, kosmologis dan sosiologisnya.

\section{B. Pendidikan, Budaya, dan Kearifan Lokal}

Kehidupan manusia dikelilingi oleh budaya, hal ini disebabkan karena manusia selalu berupaya mempertahankan eksistensinya dalam kehidupan yang mengharuskannya selalu bersinggungan dengan lingkungan sekitar, baik lingkungan fisik dan non fisik. Proses pembentukan budaya berlangsung berabad-abad dan teruji sehingga membentuk suatu komponen yang handal, terbukti dan diyakini dapat membawa

${ }^{1}$ http://sosbud.kompasiana.com/2013/12/17/pendidikan-karakter-berbasiskearifan-budaya-lokal-619934.html (Akses 17 Oktober 2014). 
Nadlir

kesejahteraan lahir dan batin. Komponen inilah yang disebut dengan jati diri.

Di dalam jati diri terkandung kearifan lokal (local wisdom) yang merupakan hasil dari local genius dari berbagai suku bangsa, kearifan lokal inilah seharusnya dirajut dalam satu kesatuan kebudayaan (culture) untuk mewujudkan suatu bangsa, yaitu Bangsa Indonesia. Budaya dilahirkan beribu tahun yang lalu sejak manusia ada di Bumi. Kebiasaan yang bagai telah menjadi dan membentuk perilaku manusia tersebut diwariskan dari generasi ke generasi selanjutnya. ${ }^{2}$

Budaya itu sendiri merupakan suatu produk dari akal budi manusia, setidaknya apabila dilakukan pendekatan secara etimologi. Budaya dalam hal ini disebut kebudayaan sangat erat kaitannya dengan masyarakat. Dalam pergiliran budaya antar generasi ini dibutuhkan adanya generasi perantara yang sudah mampu melakukan pemahaman dari generasi tua dan mampu mengkomunikasikan ke dalam bahasa yang ringan dan mudah dimengerti oleh generasi selanjutnya. ${ }^{3}$

\section{Identifikasi Kearifan Lokal}

Kearifan dapat diidentifikasi berdasarkan wilayah administratif, area kawasan ataupun golongan-golongan sosial. Ketika dikatakan lokal, maka hal ini merujuk pada spesifikasi tertentu yang berbeda dengan komunitas yang lain. Kearifan lokal lahir sebagai buah kreativitas suatu komunitas dalam memecahkan masalah atau memenuhi kebutuhannya dengan memanfaatkan potensi manusia dan sumberdaya alam yang terdapat pada tempat tinggal hidupnya sehari-hari. Adanya

\footnotetext{
2 http://sosbud.kompasiana.com/2013/12/17/pendidikan-karakter-berbasiskearifan-budaya-lokal-619934.html (Akses 17 Oktober 2014).

${ }^{3}$ Irwan Abdullah, Konstruksi dan Reproduksi Kebudayaan (Yogyakarta: Pustaka Pelajar, Cet. III, 2009).
}

Jurnal Pendidikan Agama Islam

Volume 02 Nomor 02 November 2014

Hal $302-330$ 
perbedaan potensi antar komunitas telah menghasilkan bermacam-macam kearifan yang berbeda satu sama lain sebagai sebuah kekayaan cara pandang, nilai-nilai, konsep, teori-teori, metode, teknik, maupun berbagai pilihan media atau alat/bahan yang dipakai dalam penguasaan, pengelolaan maupun pemanfaatan sumberdaya yang dimiliki komunitas tersebut.

Kearifan itu sendiri merujuk pada sebuah nilai universal tentang keadilan sosial, kesejahteraan masyarakat dan kelestarian sumberdaya penghidupan masyarakat yang melandasi pola hubungan antar warga maupun dengan komunitas yang lain. Tidak disebut kearifan bilamana yang terjadi adalah sebuah ketidakadilan, kemiskinan, kelaparan, kerusakan ekosistem dan penindasan. ${ }^{4}$ Dengan demikian menjadi sangat penting untuk meninjau kembali keberadaan sistem lokal serta dinamika perubahannya untuk dapat dikatakan sebagai sebuah kearifan. ${ }^{5}$

Kadang-kadang sulit untuk mengidentifikasi bentuk kearifan lokal yang terdapat pada sebuah komunitas, apalagi setelah perangkat komunikasi interlokal telah berkembang sedemikian rupa sehingga hubungan antar komunitas lokal pada berbagai wilayah bumi menjadi sangat mudah. Interaksi antar komunitas ini telah melahirkan berbagai bentuk lokalitas system maupun perangkat penyusunnya yang baru. Bertemunya ide-ide, teori-teori maupun metode-metode antar komunitas ini telah melahirkan suatu bentuk baru yang dapat berupa kearifan. Apalagi kondisi alam maupun lingkungan sosial telah berubah sedemikian rupa dengan pola yang relatif

\footnotetext{
${ }^{4}$ Bima Widjajaputra, "Penyelenggaraan Pendidikan Berbasis Kearifan Lokal dan Hak-hak Anak", dalam Rambu-Rambu Pelaksanaan Pendidikan Berbasis Kearifan Lokal dan Hak-Hak Anak (Bantul: SD Sendangsari, 2008), 2-3.

${ }^{5}$ Abd. Haris, Strategi Pengembangan Perguruan Tinggi Islam Berbasis Kearifan Lokal di Tengah Tantangan Globalisasi, Makalah tidak Publikasi (2010).
} 
Nadlir

sama pada berbagai belahan bumi, yang tentu saja akan mendorong munculnya kearifan-kearifan baru yang relatif sama antar komunitas meskipun masih menampakkan kekhasannya masing-masing. ${ }^{6}$

Sistem sosial terbangun dari hubungan antar manusia dan dengan lingkungan tempat tinggal hidupnya. Penguasaan, pengelolaan dan pemanfaatan sumberdaya lingkungan oleh manusia adalah sebuah bentuk interaksi dan adaptasi manusia dengan lingkungannya. Lingkungan akan berubah akibat perilaku manusia tetapi lingkungan juga akan mempengaruhi perilaku manusia. Alam dapat hidup tanpa manusia, manusia tidak dapat hidup tanpa alam. Dengan demikian maka kearifan adalah identik dengan penghargaan manusia atas sumberdaya alam yang mendukung kehidupannya yang tercermin pada pengetahuan dan perilaku sehari-hari.

Hal itu dapat bertahan atau diperbaharui melalui perkembangan pengetahuan komunitas dari waktu ke waktu serta perubahan alam itu sendiri. Bentuk kearifan lokal akan lebih mudah diidentifikasi melalui proses pendidikan tentang kehidupan sehari-hari yang dikembangkan oleh komunitas baik proses/ cara/ metodenya maupun isinya. Adat-istiadat, tembang, dongeng, permainan-permainan, teknik-teknik bercocok tanam, teknik mengolah hasil bumi, berbagai peraturan dan kesepakatan lokal, dan lain-lain, merupakan salah satu wujud sistem pendidikan lokal. Dengan menelusuri kecenderungan dan perubahan pemahaman serta perilaku masyarakat serta akibat-akibatnya pada masyarakat dan lingkungan, maka kearifan tersebut akan dikenali bentuknya.

Pemahaman dan perilaku masyarakat dapat dibaca melalui: ${ }^{7}$ 1. Norma-norma lokal yang dikembangkan, seperti

\footnotetext{
${ }^{6}$ Bima Widjajaputra, "Penyelenggaraan Pendidikan Berbasis Kearifan Lokal..., 4.

${ }^{7}$ Bima Widjajaputra, "Penyelenggaraan Pendidikan Berbasis Kearifan Lokal..., 5. 
"Laku Jawa", pantangan dan kewajiban; 2. Ritual dan tradisi masyarakat serta makna di baliknya; 3. Lagu-lagu rakyat, legenda, mitos dan ceritera rakyat yang biasanya mengandung pelajaran atau pesan-pesan tertentu yang hanya dikenali oleh komunitas lokal; 4. Informasi data dan pengetahuan yang terhimpun pada diri sesepuh masyarakat, tetua adat, pemimpin spiritual; 5. Manuskrip atau kitab-kitab suci yang diyakini kebenarannya oleh masyarakat; 6. Cara-cara komunitas lokal dalam memenuhi kehidupannya sehari-hari; 7. Alat bahan yang dipergunakan untuk kebutuhan tertentu; 8. Kondisi sumberdaya alam/ lingkungan yang biasa dimanfaatkan dalam penghidupan masyarakat.

\section{Pengertian Pendidikan Berbasis Kearifan Lokal}

Pengertian Kearifan Lokal dilihat dari kamus Inggris Indonesia, terdiri dari 2 kata yaitu kearifan (wisdom) dan lokal (local). Local berarti setempat dan wisdom sama dengan kebijaksanaan. Dengan kata lain maka local wisdom dapat dipahami sebagai gagasan-gagasan, nilai-nilai, pandanganpandangan setempat (local) yang bersifat bijaksana, penuh kearifan, bernilai baik, yang tertanam dan diikuti oleh anggota masyarakatnya.

Hasil bumi, kreasi seni, tradisi, budaya, pelayanan, jasa, sumber daya alam, sumber daya manusia atau lainnya yang menjadi keunggulan suatu daerah. Suatu proses dan realisasi peningkatan nilai dari suatu potensi daerah sehingga menjadi produk/jasa atau karya lain yang bernilai tinggi, bersifat unik, memiliki keunggulan komparatif dan kompetitif.

Apabila dilihat dari pengertiannya, maka kearifan lokal dan keunggulan lokal memiliki hubungan, yaitu kearifan lokal merupakan kebijakan manusia dalam mengembangkan 
keunggulan lokal yang bersandar pada filosofi nilai-nilai, etika, cara-cara dan perilaku yang melembaga secara tradisional.

Model pendidikan berbasis kearifan lokal merupakan model pendidikan yang memiliki relevansi tinggi bagi pengembangan kecakapan hidup (life skills) dengan bertumpu pada pemberdayaan ketempilan dan potensi lokal di masingmasing daerah. Dalam model pendidikan ini, materi pembelajaran harus memiliki makna dan relevansi tinggi terhadap pemberdayaan hidup mereka secara nyata, berdasarkan realitas yang mereka hadapi. Kurikulum yang harus disiapkan adalah kurikulum yang sesuai dengan kondisi lingkungan hidup, minat, dan kondisi psikis peserta didik. Juga harus memerhatikan kendala-kendala sosiologis dan kultural yang mereka hadapi.

Pendidikan berbasis kearifan lokal adalah pendidikan yang mengajarkan peserta didik untuk selalu lekat dengan situasi konkret yang mereka hadapi. Paulo Freire, filsuf pendidikan dalam bukunya, Cultural Action for Freedom (1970), menyebutkan, dengan dihadapkan pada problem dan situasi konkret yang dihadapi, peserta didik akan semakin tertantang untuk menanggapinya secara kritis.

Dalam pembelajaran, harus ditanamkan pada pikiran anak-anak, bahwa manusia tidak sekadar hidup (to live), namun juga bereksistensi (to exist). Sehingga, mereka termotivasi untuk berusaha mengatasi situasi serba terbatasnya. ${ }^{8}$ Artinya, mereka harus dididik bersama-sama menghadapi realitas pahit yang menimpanya sebagai persoalan yang mau tak mau harus dihadapi, bukan direduksi dan dihindari. Sehingga, mereka mampu berpikir secara kritis dan kreatif dalam merespon kondisi sosio-kulturalnya. Hal ini

\footnotetext{
${ }^{8}$ Tobroni, Relasi Kemanusiaan dalam Keagamaan (Mengembangka Etika Sosial Melalui Pendidikan) (Bandung: CV. Karya Putra Darwati, 2012).

Jurnal Pendidikan Agama Islam

Volume 02 Nomor 02 November 2014

Hal 306 - 330
} 
sesuai dengan istilah yang disebut Freire (1970) sebagai pendidikan sejati, dimana pendidikan mampu mendorong peserta didik menjadi pribadi sadar (corpo consciente) dalam relasinya dengan sesama manusia dan lingkungan di sekitarnya. ${ }^{9}$

Pendidikan berbasis kearifan lokal adalah pendidikan yang mengajarkan peserta didik untuk selalu dekat dengan situasi konkret yang mereka hadapi sehari-hari. Model pendidikan berbasis kearifan lokal merupakan sebuah contoh pendidikan yang mempunyai relevansi tinggi bagi kecakapan pengembangan hidup, dengan berpijak pada pemberdayaan ketrampilan serta potensi lokal pada tiap-tiap daerah.

Kearifan lokal sangat banyak dan beraneka ragam karena Indonesia terdiri atas bermacam-macam suku bangsa, berbicara dalam aneka bahasa daerah, serta menjalankan ritual adat istiadat yang berbeda-beda pula. Kehadiran pendatang dari luar seperti etnis Tionghoa, Arab dan India semakin memperkaya kemajemukan kearifan lokal.10

Pendidikan berbasis kearifan lokal dapat digunakan sebagai media untuk melestarikan potensi masing-masing daerah. Kearifan lokal harus dikembangkan dari potensi daerah. Potensi daerah merupakan potensi sumber daya spesifik yang dimiliki suatu daerah tertentu.

Pendidikan sejatinya adalah proses, yaitu "proses memanusiakan manusia" seutuhnya. Fitrah manusia yang telah dianugerahkan potensi akal dan budi oleh Tuhan sudah sepatutnya dimuliakan melalui proses memanusiakan manusia. Oleh karena itu, penyelenggaraan pendidikan harus dimulai

${ }^{9}$ Eri Irawan, dalam http://researchengines.educationcreativity.com/0106eri. html (Akses 17 Oktober 2014).

${ }^{10}$ Anna Sri Marlupi, Pendidikan Berbasis Kearifan Lokal, dalam http://www. pangudiluhur.org/berita/pendidikan-berbasis-kearifan-lokal-oleh-anna-srimarlupi-s-s.104.html (Akses pada 17 Oktober 2014). 
dari bagaimana cara "memaknai pendidikan sebagai suatu proses mamanusiakan manusia". Haknya untuk mengembangkan diri dipenuhi dan martabatnya sebagai manusia harus dihormati.

Apabila menelisik jauh ke belakang mengenai penyelenggaraan pendidikan konvensional, secara praktis banyak muncul problem yang pada dasarnya bermuara pada lalainya para penyelenggara pendidikan, baik formal, non formal, bahkan informal, yang sering memposisikan manusia sebagai objek. Dengan pola seperti ini, proses memanusiakan manusia sangat sulit dicapai. Peserta didik dipandang sebagai objek yang "tidak tahu", sedangkan guru sebagai subjek yang "serba tahu". Guru menjelaskan siswa hanya mendengar. Akhirnya, penyelenggaraan pendidikan sebanyak-banyaknya mentransfer pengetahuan kepada peserta didik tanpa memandang fitrah potensi sebagai manusia.

Pengetahuan seolah sangat terbatas bagi peserta didik, karena sumber pengetahuan lebih banyak bersumber pada guru. Gaya pendidikan seperti ini tidak mendorong peserta didik bereksplorasi mengembangkan pengetahuan dan potensi dirinya. Praktik penyelenggaraan pendidikan dengan gaya tersebut, tidak dapat dipungkiri sampai dengan saat ini pun masih banyak ditemukan di Indonesia. Walaupun sebenarnya pemerintah mulai dari tahun 2004 telah mengubah paradigma kurikulum untuk menciptakan pembelajaran yang berpusat pada siswa (Active Learning).

Oleh karenanya, pendidikan harus sedapat mungkin memberikan independensi kepada peserta didik untuk dapat menghargai dan mengembangkan potensinya. Mengenalkan kembali nilai-nilai kearifan lokal di sekolah-sekolah setidaknya dapat terus menguatkan budaya lokal agar tidak hilang dan ditinggalkan oleh masyarakat. Penulis melihat kecenderungan 
ini mulai muncul perlahan. Seberapa banyak siswa sekolah, mahasiswa, bahkan masyarakat yang tahu dan paham dengan slogan-slogan berbau kearifan lokal.

Pengetahuan mengenai nilai-nilai budaya atau kearifan lokal sering hanya diketahui oleh tokoh-tokoh masyarakatnya atau tersimpan di arsip Dinas Kebudayaan dan Pariwisata. Upaya diseminasi nilai-nilai kearifan lokal selama ini belum berjalan optimal baik dilakukan secara formal, non formal, maupun informal. Padahal sebenarnya, internalisasi nilai-nilai kearifan lokal akan sangat efektif jika dimulai di dalam keluarga terlebih dahulu. Tetapi, langkah ini pun sekarang sudah sangat jarang dilakukan karena keterbatasan orang tua atau bahkan tidak ada rasa kepedulian melestarikan nilai-nilai kearifan budaya lokal. Kesadaran akan pentingnya melestarikan budaya lokal belum sepenuhnya dimiliki oleh masyarakat sehingga tidak ada rasa memiliki dan menjaganya.

Pertimbangan memasukkan nilai-nilai kearifan lokal dalam kurikulum di sekolah pada dasarnya lebih menitikberatkan pada upaya membentengi siswa akan pengaruh budaya luar yang sebenarnya belum tentu sesuai dengan tatanan dan norma di masyarakat lokal. Penulis dalam hal ini tidak menolak kemajuan teknologi dan informasi dari luar, tetapi harus dipahami bahwa siswa, guru, dan orang tua harus lebih selektif mengawal konten teknologi dan informasi yang saat ini berkembang. ${ }^{11}$

Selain itu, masuknya konten kearifan lokal ke dalam kurikulum di sekolah merupakan salah satu komitmen sekolah dalam rangka mewujudkan pendidikan karakter serta mendukung pelestarian kearifan lokal. Kurikulum yang dimaksudkan disini bukan dipahami sebagai bentuk mata

${ }^{11}$ Dinar Pratama, dalam http://bangka.tribunnews.com/2014/05/21/opinipendidikan-karakter-berbasis-kearifan-lokal (Akses pada 17 Oktober 2014). 
pelajaran yang terjadwal secara khusus di sekolah (formal curriculum). Tetapi, kurikulum yang dimaksud disini lebih pada penerapan hidden curriculum (kurikulum yang tidak tertulis). Kurikulum ini merupakan penerapan budaya sekolah yang biasanya berisikan nilai, norma, dan kepercayaan atau keyakinan yang ditransformasikan baik di dalam kelas maupun di lingkungan sosial siswa. Guru dapat mentransfer nilai-nilai kearifan lokal ini agar terintegrasi dengan materi pelajaran dan senantiasa disampaikan untuk semua mata pelajaran.

Sebenarnya transformasi nilai-nilai kearifan lokal ini mungkin sudah pernah disampaikan baik secara langsung maupun tidak langsung oleh sekolah dan guru-guru. Akan tetapi belum ada komitmen secara kolektif dalam penerapannya. Oleh karenanya, pemerintah perlu merumuskan kebijakan terkait dengan pentingnya mengetahui, memahami, dan mengamalkan nilai-nilai kearifan lokal.

Pendidikan berbasis kearifan lokal adalah pendidikan yang memanfaatkan keunggulan lokal dan global dalam aspek ekonomi, seni budaya, SDM, bahasa, teknologi informasi dan komunikasi, ekologi, dan lain-lain ke dalam kurikulum sekolah yang akhirnya bermanfaat bagi pengembangan kompetensi peserta didik yang dapat dimanfaatkan untuk persaingan global.

Pendidikan bebasis kearifan lokal adalah pendidikan yang lebih didasarkan kepada pengayaan nilai-nilai kultural. Pendidikan ini mengajarkan peserta didik untuk selalu dekat dengan situasi konkret yang mereka hadapi sehari-hari. Dengan kata lain model pendidikan ini mengajak kepada semua orang untuk selalu dekat dan menjaga keadaan sekitar yang bersifat nilai yang berada di dalam lokal masayarakat tersebut. 


\section{E. Gagasan dan Dasar Hukum Pendidikan Berbasis Kearifan Lokal}

Gagasan tentang pendidikan berbasis kearifan lokal ini berawal dari sebuah ungkapan yang disampaikan oleh Jhon Naisbit (1990) yang kemudian direspon dan dikembangkan oleh sebagian para pakar sosial dengan ungkapan "thinks globally acts locally" (berpikir global dan bertindak lokal). Maksud dari ungkapan tersebut adalah, seseorang bisa mengambil pengalaman dan pengetahuan apapun, dari suku manapun dan bangsa manapun, akan tetapi dalam pengaplikasiannya dalam sebuah tindakan ketika seseorang berada di dalam suatu tempat, maka ia harus menyesuaikan dengan nilai dan budaya yang ada di tempat tersebut.

Dengan adanya pengetahuan yang bersifat global, seseorang akan dapat dengan mudah membaca dan mengenali suatu masalah dan memecahkannya. Maka dari itu seseorang perlu untuk berpengetahuan banyak agar wawasan menjadi relatif luas. Akan tetapi dalam hal pendidikan pada umumnya dan belajar mengajar khususnya, seorang pendidik tidak cukup hanya dengan berpengetahuan banyak dan berwawasan luas, akan tetapi untuk merefleksikan transfer of knowladge (proses pembelajaran) tersebut juga harus disertai dengan emotion skill (kemampuan emosi) yaitu bagaimana seorang pendidik harus bisa masuk ke dalam dunia dimana anak didik tersebut berada. ${ }^{12}$

Dalam masalah ini ada satu hal yang perlu diingat yaitu "seorang anak didik yang datang ke sebuah kelas dalam suatu sekolah tidaklah seperti gelas kosong, akan tetapi mereka sudah membawa pengetahuan dan kebiasaan-kebiasaan dari tempat di mana ia tinggal". Dengan kata lain bahwa lingkungan

${ }^{12}$ J. Parker Palmer, Keberanian Mengajar (Jakarta: Permata Puri Media, 2009). 
Nadlir

yang menjadi tempat tinggal seorang peserta didik yang satu, berbeda dengan lingkungan yang menjadi tempat tinggal peserta didik yang lain. Dengan begitu sudah barang tentu bahwa status sosial dan ekonomi merekapun pasti berbedabeda. Begitu juga dalam lokal masyarakat, di dalam sebuah lokal masyarakat yang satu, pasti akan berbeda dengan lokal masyarakat yang lain. Itulah sebabnya kenapa di Indonesia ada semboyan "Bineka Tunggal Ika" yang maksud dari semboyan tersebut adalah walaupun berasal dari suku yang berbeda serta budaya yang berbeda pula, akan tetapi memiliki satu kesatuan yaitu Indonesia. ${ }^{13}$

Dari kata semboyan yang tersebut di atas bisa disimpulkan bahwa negara Indonesia memang telah mempunyai banyak sekali lokal masyarakat yang tentunya memiliki keanekaragaman budaya yang berbeda- beda pula. Maka dari itu sudah barang tentu bahwa negara Indonesia sebenarnya telah memiliki kekayaan budaya yang pastinya bisa memberi sebuah warna dan corak yang bisa dikembangkan menjadi sebuah karakter bangsa.

Pendidikan bebasis kearifan lokal sebenarnya adalah bentuk refleksi dan realisasi dari Peraturan Pemerintah (PP) Nomor 19/2005 tentang Standar Nasional Pendidikan, yaitu pasal 17 ayat 1 yang menjelaskan bahwa "kurikulum tingkat satuan pendidikan SD-SMA, atau bentuk lain yang sederajat dikembangkan sesuai dengan satuan pendidikan, potensi daerah, sosial budaya, dan peserta didik".

Sekolah, terutama di daerah sering menjadi "jajahan" sistem pendidikan yang dibuat pusat. Selera lokalitas dalam berkreasi dalam dunia pendidikan di daerah pun seakan semu, tidak terlihat, kalaupun ada sebatas mata pelajaran muatan

\footnotetext{
${ }^{13}$ Lawrence A. Blum, Antirasisme, Multikulturalisme, dan Komunitas Antar-Ras (Yogyakarta: Tiara Wacana, 2001).
}

Jurnal Pendidikan Agama Islam Volume 02 Nomor 02 November 2014

Hal $312-330$ 
lokal, seperti pencak silat atau seni tari, yang terlihat secara fisik saja. Adapun pembentukan karakter melalui penanaman nilai khas kedaerahan seakan luput tidak terjamah. Padahal angin segar desentralisasi pendidikan sudah berhembus lama dan berdengung kencang seiring dengan lahirnya otonomi daerah. ${ }^{14}$ Dari situ, perlu dirumuskan pendidikan berbasis kearifan lokal.

\section{F. Urgensi Pendidikan Berbasis Kearifan Lokal}

Dewasa ini terdapat gejala dekulturasi atau pemudaran budaya lokal dalam berbagai bentuk, salah satunya adalah dalam pola pemberian nama. Nama-nama siswa didominasi nama asing yang terkesan modern. Bahkan ada siswa yang malu dengan namanya sendiri yang khas dengan nama Jawa karena menjadi bahan tertawaan teman-temannya.

Para siswa juga lebih hafal lagu-lagu pop modern dan lagu-lagu Barat dibandingkan dengan lagu-lagu daerah. Kenyataan semacam itu tentu memprihatinkan. Setelah batik, reog, lagu Rasa Sayange, dan tari Pendet "dianggap milik Malaysia", bukan tidak mungkin, suatu saat akan semakin banyak kearifan lokal yang diklaim budaya milik negara tetangga.

Arus penetrasi kebudayaan yang datang dari Barat semakin gencar mewarnai sistem kehidupan sosiokultural masyarakat Indonesia. Di perparah lagi dengan adanya kecenderungan sebahagian generasi muda bangsa ini berkiblat kepada kepada kebudayaan tersebut. Keadaan akan tampak semakin konkrit ketika mencoba melihat fenomena yang ada

14 Akhsan Sukroni, Pendidikan Karakter Berbasis Kearifan Lokal, dalam http://www.unmabanten.ac.id/index.php/kumpulan-artikel-opini/140pendidikan-karakter-berbasis-kearifan-lokal (Akses pada 17 Oktober 2014). 
seperti maraknya pergaulan bebas, kasus narkoba dan sebagainya.

Di tengah pusaran pengaruh hegemoni global tersebut, fenomena yang terjadi juga telah membuat lembaga pendidikan serasa kehilangan ruang gerak. Selain itu juga membuat semakin menipisnya pemahaman peserta didik tentang sejarah lokal serta tradisi budaya yang ada dalam masyarakat. Oleh karena itu maka alangkah lebih baiknya jika diupayakan bagaimana caranya agar aneka ragam budaya yang telah dimiliki tersebut bisa dijaga dan dilestarikan bersama.

Dengan pendidikan yang berbasis pada local wisdom (kearifan lokal) maka seseorang bisa optimis akan terciptanya pendidikan yang mampu memberi makna bagi kehidupan manusia Indonesia. Artinya pendidikan kemudian akan mampu menjadi spirit yang bisa mewarnai dinamika manusia Indonesia kedepan. ${ }^{15}$ Pendidikan nasional harus mampu membentuk manusia yang berintegritas tinggi dan berkarakter sehingga mampu melahirkan anak-anak bangsa yang hebat dan bermartabat sesuai dengan spirit pendidikan yaitu memanusiakan manusia.

Setiap manusia memiliki potensi bawaan yang akan termanisfestasi setelah dia dilahirkan, termasuk potensi yang terkait dengan karakter atau nilai-nilai kebajikan. Dalam hal ini, Confusius -seorang filsuf terkenal Cina- menyatakan bahwa anak pada dasarnya memiliki potensi mencintai kebajikan, namun bila potensi ini tidak diikuti dengan pendidikan dan sosialisasi setelah anak dilahirkan, maka anak dapat berubah

15 Benni Setiawan, Agenda Pendidikan Nasional (Yokyakarta: Ar-Ruz Media Group, 2008).

Jurnal Pendidikan Agama Islam

Volume 02 Nomor 02 November 2014

Hal $314-330$ 
menjadi binatang, bahkan lebih buruk lagi. ${ }^{16}$ Oleh karena itu, sosialisasi dan pendidikan masyarakat yang berkaitan dengan nilai-nilai kebajikan baik di keluarga, sekolah, maupun lingkungan yang lebih luas sangat penting dalam pembentukan karakter seseorang.

Salah satu nilai yang dapat dijadikan sebagai pijakan pembangunan karakter anak adalah nilai-nilai kebaikan sebuah daerah yang sudah mengakar kuat sebagai sistem budaya, yang kemudian disebut sebagai kearifan lokal. Kearifan lokal menjadi sebuah tawaran yang menarik untuk pengembangan pendidikan karakter, karena pada dasarnya pengembangan karakter harus diikuti dengan pengintegrasian jati diri kebangsaan pada diri anak, jati diri kebangsaan atau nasionalisme pasti akan berkait erat dengan jejaring kebudayaan bangsa yang menjadi basis kebudayaan nasional.

Pada dasarnya kearifan lokal merupakan kebenaran yang telah mentradisi atau ajeg dalam suatu daerah. Kearifan lokal merupakan perpaduan antara nilai-nilai suci firman Tuhan dan berbagai nilai kebaikan yang ada. Kearifan lokal terbentuk sebagai keunggulan budaya masyarakat setempat maupun kondisi geografis dalam arti luas.

Kearifan lokal merupakan produk budaya masa lalu yang patut secara terus-menerus dijadikan pegangan hidup. Meskipun bernilai lokal tetapi nilai yang terkandung di dalamnya dianggap sangat universal. Sehingga dengan mengintegrasikan kearifan lokal dalam desain pembentukan karakter anak, secara tidak langsung anak akan mendapatkan gambaran yang utuh atas identitas dirinya sebagai individu, serta identitas dirinya sebagai anggota masyarakat yang terikat

${ }^{16}$ Khasan Ubaidillah, "Integrasi Kearifan Lokal dalam Pendidikan Karakter", dalam http://qudsiyyah.com/2013/12/integrasi-kearifan-lokal-dalampendidikan-karakter/ (Akses 17 Oktober 2014). 
dengan budaya yang unggul dan telah lama diugemi para pendahulunya. ${ }^{17}$

Kearifan lokal merupakan pengetahuan yang eksplisit yang muncul dari periode panjang, yang berevolusi bersamasama masyarakat dan lingkungannya dalam sistem lokal yang sudah dialami bersama-sama. Proses evolusi yang begitu panjang dan melekat dalam masyarakat, dapat menjadikan kearifan lokal sebagai sumber energi potensial dari sistem pengetahuan kolektif masyarakat, untuk hidup bersama secara dinamis dan damai.

Kearifan lokal yang digali, dipoles, dikemas, dipelihara dan dilaksanakan dengan baik bisa berfungsi sebagai alternatif pedoman hidup manusia. Nilai-nilai itu dapat digunakan untuk menyaring nilai-nilai baru atau asing, agar tidak bertentangan dengan kepribadian bangsa dan menjaga keharmonisan hubungan manusia dengan Sang Khalik, alam sekitar dan sesamanya. Selain itu, kearifan lokal dapat menjadi benteng kokoh menanggapi modernitas dengan tidak kehilangan nilainilai tradisi lokal yang telah mengakar dalam sebuah komunitas masyarakat atau daerah.

Dalam pendidikan berbasis kearifan lokal, pedoman nilainilai kearifan lokal merupakan kriteria yang menentukan kualitas tindakan anak. Sebagai sebuah kriteria yang menentukan, nilai-nilai kearifan lokal bisa menjadi sebuah pijakan untuk pengembangan sebuah pembelajaran yang lebih berkarakter. Kebermaknaan pembelajaran dengan lingkup kearifan lokal akan menampilkan sebuah dimensi pembelajaran yang selain memacu keilmuan seseorang, juga sekaligus bisa mendinamisasi keilmuan tersebut menjadi kontekstual dan ramah budaya daerah.

${ }^{17}$ Majalah El-Qudsy, Edisi 21 tahun 2013.

Jurnal Pendidikan Agama Islam

Volume 02 Nomor 02 November 2014

Hal $316-330$ 
Menggali dan menanamkan kembali kearifan lokal secara inheren melalui pembelajaran, dapat dikatakan sebagai gerakan kembali pada basis nilai budaya daerahnya sendiri, sebagai bagian upaya membangun identitas bangsa dan sebagai semacam filter dalam menyeleksi pengaruh budaya "lain".18 Nilai-nilai kearifan lokal itu meniscayakan fungsi yang strategis bagi pembentukan karakter dan identitas bangsa. Pendidikan yang menaruh peduli terhadapnya, akan bermuara pada munculnya sikap yang mandiri, penuh inisiatif, santun dan kreatif.

Salah satu aplikasi pemanfaatan nilai-nilai kearifan lokal sebagai basis pendidikan, misalnya apabila di daerah terdekat sekolah itu terdapat filosofi hidup yang merupakan landasan nilai kehidupan daerah tersebut, seperti filosofi alon-alon asal klakon (masyarakat Jawa Tengah), rawe-rawe rantas malangmalang putung (masyarakat Jawa Timur), atau Gusjigang (masyarakat Kudus) dan masih banyak lagi. ${ }^{19}$ Maka guru dalam pembelajaran harus memulai memunculkan dan menginternalisasikan nilai-nilai kearifan lokal tersebut, sebagai pijakan dan spirit dalam setiap mendidik siswanya. Sehingga dari pola yang demikian, guru akan menjadi seorang fasilitator yang baik bagi internalisasi nilai-nilai kearifan lokal pada diri peserta didik yang bersinggungan langsung dalam proses pembelajaran.

Pada posisi ini, nilai yang terkandung dalam bingkai kearifan lokal sebuah daerah akan menjadi senjata yang ampuh untuk membangun karakter anak bangsa, agar memiliki jiwa nasionalisme yang tinggi sekaligus mampu menjadi penjaga

\footnotetext{
${ }^{18}$ Majalah El-Qudsy, Edisi 21 tahun 2013

${ }^{19}$ Khasan Ubaidillah, "Integrasi Kearifan Lokal dalam Pendidikan Karakter", dalam http://qudsiyyah.com/2013/12/integrasi-kearifan-lokal-dalampendidikan-karakter/ (Akses 17 Oktober 2014).
} 
Nadlir

kelestarian kearifan lokal tersebut melalui sikap keseharian yang berkarakter kuat.

\section{G. Implementasi Pendidikan Berbasis Kearifan Lokal}

Pendidikan memiliki peranan yang amat penting dalam meningkatkan sumber daya manusia. Melalui pendidikan diharapkan akan menghasilkan sumber daya manusia Indonesia yang berkualitas. Jika menilik pada tujuan pendidikan nasional, maka manusia yang berkualitas tidak hanya terbatas pada tataran kognitif, tetapi juga afektif dan psikomotor.

Pada praktiknya, mata pelajaran muatan lokal dipandang merupakan pelajaran kelas nomor dua dan hanya dianggap sebagai pelengkap. ${ }^{20}$ Sekolah-sekolah menerapkannya sebatas formalitas untuk memenuhi tuntutan kurikulum yang dituangkan dalam berbagai peraturan. Kondisi demikian mengindikasikan aplikasi pengajaran muatan lokal di sekolah masih mengambang. Persoalannya adalah bagaimana penerapan konsep pendidikan yang sudah dimasukkan ke dalam kurikulum tersebut.

Semua stakeholder pendidikan diharapkan memberikan kontribusi nyata terhadap pelestarian kebudayaan lokal di daerah khusunya bagi kalangan pemuda sebagai penerus budaya bangsa. Pemberian pengarahan dan penghargaan kepada para guru juga dianggap perlu dalam upaya memotivasi dan meningkatkan pemahaman para guru dalam mengaplikasikan serta memberikan teladan mengenai pendidikan karakter berbasis kearifan budaya lokal.

\footnotetext{
${ }^{20}$ http://sosbud.kompasiana.com/2013/12/17/pendidikan-karakter-berbasiskearifan-budaya-lokal-619934.html (Akses 17 Oktober 2014).

Jurnal Pendidikan Agama Islam

Volume 02 Nomor 02 November 2014

Hal 318 - 330
} 
Contoh implementasi kecil yang dapat direalisasikan di lembaga pendidikan misalnya dengan mengadakan kegiatankegiatan kesiswaan yang menekankan pada pengenalan budaya lokal yang isi dan media penyampaiannya dikaitkan dengan lingkungan sosial dan lingkungan budaya serta kebutuhan pembangunan daerah setempat yang perlu diajarkan kepada para pemuda. Pengadaan sanggar seni budaya di sekolahsekolah sebagai sarana merealisasikan bakat juga sebagai hiburan para pelajar, juga dipandang perlu untuk meningkatkan pengetahuan dan kecintaan para pemuda pada kebudayaan lokal di daerahnya sendiri.

Permainan-permainan tradisional yang hampir punah juga sebaiknya diekspos kembali. Gasing, misalnya, sebagai permainan tradisional, ia dapat membawa banyak manfaat dan perlu dilestarikan karena mengandung nilai sejarah, dapat dijadikan simbol atau maskot daerah, dijadikan cabang olahraga yang dapat diukur dengan skor dan prestasi dan mengandung nilai seni. Masih banyak lagi permainanpermainan tradisional yang mengandung unsur kekompakan tim, kejujuran, dan mengolah otak selain berfungsi sebagai hiburan juga untuk menanamkan kecintaan pelajar pada budaya lokal di daerah.

Selain itu, penggunaan bahasa lokal dipandang perlu diaplikasikan paling tidak satu hari dalam enam hari proses pembelajaran di sekolah. Disamping itu, diharapkan kegiatankegiatan ekstrakurikuler berbasis kebudayaan lokal mulai diadakan di sekolah-sekolah. Kegiatan seperti perlombaan majalah dinding sekolah, dengan isi yang menekankan pada pengenalan budaya lokal, lomba cerdas cermat antar pelajar mengenai lingkungan sosial dan lingkungan budaya serta kebutuhan pembangunan daerah setempat, dan sebagainya. 
Contoh implementasi lainnya yang dapat diterapkan di luar sekolah adalah dengan aktif mengadakan seminar (workshop) tentang pendidikan karakter dan kearifan budaya lokal kepada para pemuda. Tentunya serangkaian kegiatan tersebut dapat dilaksanakan dengan metode yang sesuai dengan gaya pemuda masa kini agar lebih menarik dan terkesan tidak kuno. Pendirian komunitas pemuda peduli budaya juga dapat menjadi inovasi dan memberikan motivasi bagi para pemuda dalam menerapkan pendidikan berbasis kearifan budaya lokal. Disamping itu, tradisi-tradisi yang menekankan pada kegotong royongan dianggap perlu diaplikasikan dan disisipkan pada kegiatan-kegiatan kesiswaan di sekolah. ${ }^{21}$

Dalam rangka mendukung proses pembelajaran para pemuda terhadap sejarah dan kebudayaan lokal, Dinas Kebudayaan dan Pariwisata sebaiknya dapat bekerja sama dengan Dinas Pendidikan untuk mendirikan museum sejarah kebudayaan dan wahana handicraft yang berisikan pernakpernik kerajinan tangan hasil karya pemuda.

Selain untuk memperkenalkan kebudayaan lokal terhadap kaum pemuda, pendidikan berbasis kearifan budaya lokal juga memiliki tujuan mengubah sikap dan juga perilaku sumber daya manusia yang ada agar dapat meningkatkan produktivitas kerja untuk menghadapi berbagai tantangan di masa yang akan datang. Manfaat dari penerapan budaya yang baik juga dapat meningkatkan jiwa gotong royong, kebersamaan, saling terbuka satu sama lain, menumbuhkembangkan jiwa kekeluargaan, membangun komunikasi yang lebih baik, serta tanggap dengan perkembangan dunia luar.

\footnotetext{
${ }^{21} \mathrm{http}: / /$ sosbud.kompasiana.com/2013/12/17/pendidikan-karakter-berbasiskearifan-budaya-lokal-619934.html (Akses 17 Oktober 2014).

Jurnal Pendidikan Agama Islam 
Budaya merupakan source yang takkan habis apabila dapat dilestarikan dengan optimal. Selain itu, apabila negara menginginkan profit jangka panjang, alternatif jawabannya adalah lestarikan budaya dengan menggunakan potensi yang dimiliki pemuda tentunya tanpa melupakan peran serta golongan tua. ${ }^{22}$

Saatnya memperkenalkan dan menerapkan kembali kebudayaan lokal yang telah lama terlupakan dan meninggalkan budaya asing yang sejatinya sangat tidak sesuai dengan budaya Indonesia. Kenapa mesti malu mengakui budaya sendiri, sedangkan bangsa asing saja mau berselisih untuk mengakui budaya Indonesia dan memperkenalkannya kepada dunia sebagai budaya mereka? Jadi semestinya bangga dengan apa yang dimiliki dan memperlihatkan kepada dunia bahwa inilah budaya daerahku.

Para siswa yang datang ke sekolah tidak bisa diibaratkan sebagai sebuah gelas kosong, yang bisa diisi dengan mudah. Siswa tidak seperti plastisin yang bisa dibentuk sesuai keinginan guru. Mereka sudah membawa nilai-nilai budaya yang dibawa dari lingkungan keluarga dan masyarakatnya. Guru yang bijaksana harus dapat menyelipkan nila-nilai kearifan lokal merka dalam proses pembelajaran.

Bagi guru Bahasa Indonesia, Bahasa Inggris dan Bahasa Jawa, dapat menugaskan para siswa untuk membuat karangan tentang potensi Wisata Kota Lama Semarang. Bagi guru Sejarah, dapat menugaskan para siswa untuk membuat laporan tentang sejarah tradisi Warak Ngendhog dan Dhugdheran dalam bentuk power point. Bagi guru Seni Rupa, dapat mengajarkan bagaimana cara menggambat rumah serotongan, limasan dan joglo khas semarangan. Bagi guru Matematika,

${ }^{22}$ http://sosbud.kompasiana.com/2013/12/17/pendidikan-karakter-berbasiskearifan-budaya-lokal-619934.html (Akses 17 Oktober 2014). 
dapat mengenalkan bentuk-bentuk geometris kepada para siswa melalui bentuk atap rumah adat. Hal-hal serupa juga dapat diterapkan oleh para guru untuk mata pelajaran-mata pelajaran yang lain. ${ }^{23}$

Metode lain yang dapat dipraktikkan adalah melalui kegiatan bercerita atau mendongeng, dengan menyertakan gambar, foto, boneka, iringan musik, miniatur rumah adat, gestik dan pembawaan guru yang menarik. Cara semacam ini sangat efektif untuk mendidik siswa di tingkat Kelompok Bermain, Taman Kanak-Kanak dan Sekolah Dasar.

Pendidikan berbasis kearifan lokal tentu akan berhasil apabila guru memahami wawasan kearifan lokal itu sendiri. Guru yang kurang memahami makna kearifan lokal, cenderung kurang sensitif terhadap kemajemukan budaya setempat. Hambatan lain yang biasanya muncul adalah guru yang mengalami lack of skill. Akibatnya, mereka kurang mampu menciptakan pembelajaran yang menghargai keragaman budaya daerah.

Cara yang bisa dilakukan oleh seorang pelaku pendidikan, baik itu pengajar ataupun peserta didik adalah dengan menggali berbagai potensi nilai yang ada dalam sebuah lokal masyarakat tersebut. Dari situlah maka seorang pelaku pendidikan tersebut akan bisa melakukan perubahan pada dunia pendidikan yang dijalani dan ditekuninya. Hal itu sesuai dengan sebuah istilah yang berasal dari salah seorang intelektual asal Maroko, yaitu Almarhum Muhammad Abed AlJabiri yang mengatakan "Attajdidu mina dhdhahl" perubahan harus berangkat dari tradisi, maksudnya bahwa perubahan bukan dengan meminjam tradisi orang ataupun bangsa lain.

23 Anna Sri Marlupi, Pendidikan Berbasis Kearifan Lokal, dalam http://www.pangudiluhur.org/berita/pendidikan-berbasis-kearifan-lokaloleh-anna-sri-marlupi-s-s.104.html (Akses pada 17 Oktober 2014).

Jurnal Pendidikan Agama Islam

Volume 02 Nomor 02 November 2014

Hal $322-330$ 
Solusi yang paling tepat, tentu saja dengan memudahkan para guru untuk memperoleh informasi akurat dari media cetak dan media elektronik. Sekolah dapat melakukannya dengan menyediakan buku-buku rujukan, kaset VCD edukatif, majalah, tabloid dan surat kabar terbaru secara rutin di perpustakaan. Sekolah juga dapat menugaskan guru untuk berpartisipasi aktif sebagai peserta dalam pelatihan, seminar dan lokakarya tentang kearifan lokal.

Para guru yang sudah mampu mendapatkan informasi secara cepat dari internet, pasti lebih aktif dalam penanaman kearifan lokal di ruang kelas. Akan lebih baik apabila guru menyebarkan "virus-virus cinta kearifan lokal" dengan rajin berbagi pengalaman, misalnya menulis di majalah, koran, maupun blog milik unit kerja masing-masing. Bahkan jika kemampuan sudah memungkinkan, guru dapat berbicara dalam seminar-seminar skala lokal maupun tingkat nasional. Peran aktif guru semacam itu sanggup memotivasi rekan-rekan sekerja untuk mempraktikkannya.

Perubahan harus dimulai sekarang, karena kearifan lokal sudah mulai dilupakan. Insan negeri ini harus belajar banyak dari bangsa Jepang yang tetap menjunjung tinggi kearifan lokal, sekalipun mereka sudah menguasai teknologi modern. Mencintai kearifan lokal, bukan berarti ketinggalan zaman.

\section{H. Tujuan Pendidikan Berbasis Kearifan Lokal}

Secara umum, pendidikan berbasis kearifan lokal bertujuan untuk memberikan bekal pengetahuan, ketrampilan dan perilaku kepada peserta didik agar mereka memiliki wawasan yang mantap tentang keadaan lingkungan dan kebutuhan masyarakat sesuai dengan nilai-nilai/aturan yang berlaku di daerahnya dan mendukung pembangunan daerah serta pembangunan nasional. 
Secara khusus pendidikan berbasis kearifan lokal bertujuan untuk:

1. Mengenal dan menjadi lebih akrab dengan lingkungan alam, sosial, dan budayanya.

2. Memberikan bekal kemampuan dan ketrampilan serta pengetahuan mengenai daerahnya yang berguna bagi dirinya maupun lingkungan masyarakat pada umumnya.

3. Membekali sikap dan perilaku yang selaras dengan nilainilai/aturan-aturan yang berlaku di daerahnya serta melestarikan dan mengembangkan nilai-nilai luhur budaya setempat dalam rangka menunjang pembangunan daerah dan pembangunan nasional.

Tujuan pendidikan berbasis kearifan lokal sesuai dengan naskah yang telah termaktub dalam undang-undang nasional yaitu Undang-undang (UU) No 20 Tahun 2003 Tentang Sistem Pendidikan Nasional pada Pasal 3, menyebutkan bahwa pendidikan nasional berfungsi mengembangkan kemampuan dan membentuk karakter serta peradaban bangsa yang bermartabat dalam rangka mencerdaskan kehidupan bangsa. Pendidikan nasional bertujuan untuk berkembangnya potensi peserta didik agar menjadi manusia yang beriman dan bertakwa kepada Tuhan Yang Maha Esa, berakhlak mulia, sehat, berilmu, cakap, kreatif, mandiri, dan menjadi warga negara yang demokratis serta bertanggung jawab. ${ }^{24}$

Sementara itu, manfaat pendidikan berbasis kearifan lokal antara lain: 1. Melahirkan generasi- generasi yang kompeten dan bermartabat; 2. Merefleksikan nilai- nilai budaya; 3. Berperan serta dalam membentuk karakter bangsa;

\footnotetext{
${ }^{24}$ Direktorat Jenderal Kesatuan Bangsa dan Politik Departemen Dalam Negeri, Peraturan Menteri dalam Negeri Nomor 39 Tahun 2007 tentang Pedoman Fasilitasi Organisasi Kemasyarakatan Bidang Kebudayaan, Keraton, dan Lembaga Adat dalam Pelestarian dan Pengembangan Budaya Daerah (2007).
}

Jurnal Pendidikan Agama Islam

Volume 02 Nomor 02 November 2014

Hal 324 - 330 
4. Ikut berkontribusi demi terciptanya identitas bangsa; 5. Ikut andil dalam melestarikan budaya bangsa.

\section{Langkah-langkah Pengembangan Kearifan Lokal}

Setiap kearifan memiliki dimensi atau muatan pendidikan yang bersifat spesifik ketika dikategorikan berdasarkan ruang materi ajar tertentu. Ketika kearifan lokal diajarkan sebagai bentuk media pengembangan diri, maka setiap orang atau pendidik akan lebih leluasa di dalam mengembangkan metode pengajarannya dan menentukan target-target kemampuan yang harus dicapai oleh peserta didik. Hal ini akan sangat berbeda jika diintegrasikan dalam setiap materi ajar yang sudah ada karena perlu dilakukan penyesuaian-penyesuaian isi/materi ajar dan proses mengajarnya. Dengan begitu, metode pengintegrasian akan berhasil jika pendidik memiliki cukup pemahaman atas materi yang diintegrasikan.

Pendidikan Berbasis Kearifan Lokal merupakan langkah maju untuk membangun nasionalisme peserta didik, yaitu mencintai produk lokal dan mampu mengembangkan nilai tambah dari produk tersebut. Dengan demikian semangat mencintai bumi tempat berpijak dan kehidupan akan berkembang terus. Cara pandang ini merupakan kearifan lokal budaya nusantara yang memang sejak merdeka sudah dianugerahi Tuhan Yang Maha Esa dengan keanekaragaman hayati terbesar di dunia.

Pembelajaran di lembaga pendidikan terdiri atas berbagai materi ajar (subject matter), dimana setiap materi tersebut sudah ditentukan target-target pembelajarannya. Tanpa mengganggu sama sekali setiap materi ajar tersebut, bahkan memperkuatnya, muatan kearifan lokal perlu dimasukkan. Apapun yang diterima peserta didik merupakan sebuah materi ajar, baik berupa teori, praktik, contoh-contoh 
Nadlir

soal maupun sikap pendidik itu sendiri. Menggambarkan secara jelas kekhasan materi ajar, ruang kelas, lingkungan pendidikan maupun buku-buku/ media pendidikan menjadi sebuah kebutuhan lembaga pendidikan agar dapat diterima efektif oleh peserta didik.

Pengintegrasian akan efektif jika muatan kearifan lokal dapat masuk menjadi materi ajar pokok yang tidak sekedar asal dapat ditempelkan. Dalam Pendidikan Agama, misalnya, perlu dapat menjelaskan hukumnya berwirausaha, berbisnis, belajar, bercocok tanam, memanfaatkan lahan kosong di bawah tegakan tanaman, mengolah makanan secara alami tanpa pewarna maupun pengawet buatan, mensyukuri kekayaan hayati, dan lain-lain.

Di dalam PKn perlu untuk menjelaskan posisi negara yang penuh hutang, perlunya membangun kemandirian ekonomi, perlunya mencintai hasil produksi dalam negeri maupun praduk lokal dan lain-lain. Materi ajar Bahasa Indonesia dapat mengarahkan kesadaran anak tentang kearifan lokal melalui pelajaran mengarang, membuat puisi ataupun membuat peribahasa dengan tema-tema lokal. Demikian pula pada IPA, IPS, Seni Budaya dan Ketrampilan, Pendidikan kesehatan, berbagai materi ajar dasar maupun pengembangan diri. ${ }^{25}$

Lebih lanjut, langkah-langkah untuk mengembangkan kearifan lokal melalui pendidikan adalah:

1. Mengidentifikasi keadaan dan kebutuhan daerah (Lingkungan alam, sosial dan budaya, Prioritas rencana pembangunan daerah jangka pendek maupun jangka panjang, Pengembangan ketenagakerjaan termasuk jenis ketrampilan dan kemampuan yang diperlukan, Aspirasi

${ }^{25}$ Bima Widjajaputra, "Penyelenggaraan Pendidikan Berbasis Kearifan Lokal..., 7.

Jurnal Pendidikan Agama Islam

Volume 02 Nomor 02 November 2014

Hal $326-330$ 
masyarakat mengenai pelestarian alam dan pengembangan daerahnya).

2. Menentukan fungsi dan tujuan (Melestarikan dan mengembangkan kebudayaan daerah, Meningkatkan ketrampilan di bidang pekerjaan tertentu, Meningkatkan kemampuan berwiraswasta, Meningkatkan penguasaan bahasa Inggris untuk keperluan sehari-hari, Meningkatkan penguasaan teknologi).

3. Menentukan kriteria bahan kajian (Kesesuaian dengan tingkat perkembangan siswa, Kemampuan guru dan ketersediaan tenaga pendidik yang diperlukan, Tersedianya sarana dan prasarana, Tidak bertentangan dengan nilai luhur bangsa, Tidak menimbulkan kerawanan sosial dan keamanan, Kelayakan pelaksanaan di sekolah).

4. Menyusun Kurikulum (Penentuan topik keunggulan lokal yang dipilih serta standar kompetensi, kemampuan dasar, dan indikator, Pengorganisasian materi atau kompetensi muatan keunggulan lokal ke dalam kelas, semester dan lainnya yang berwujud silabus).

\section{J. Penutup}

Pembelajaran di lembaga pendidikan terdiri atas berbagai materi ajar (subject matter), dimana setiap materi tersebut sudah ditentukan target-target pembelajarannya. Tanpa mengganggu sama sekali setiap materi ajar tersebut, bahkan memperkuatnya, muatan kearifan lokal perlu dimasukkan. Apapun yang diterima peserta didik merupakan sebuah materi ajar, baik berupa teori, praktik, contoh-contoh soal maupun sikap pendidik itu sendiri. Menggambarkan secara jelas kekhasan materi ajar, ruang kelas, lingkungan pendidikan maupun buku-buku/ media pendidikan menjadi sebuah 
Nadlir

kebutuhan lembaga pendidikan agar dapat diterima efektif oleh peserta didik.

Pengintegrasian akan efektif jika muatan kearifan lokal dapat masuk menjadi materi ajar pokok yang tidak sekedar asal dapat ditempelkan. Dalam Pendidikan Agama, misalnya, perlu dapat menjelaskan hukumnya berwirausaha, berbisnis, belajar, bercocok tanam, memanfaatkan lahan kosong di bawah tegakan tanaman, mengolah makanan secara alami tanpa pewarna maupun pengawet buatan, mensyukuri kekayaan hayati, dan lain-lain.

Di dalam PKn perlu untuk menjelaskan posisi negara yang penuh hutang, perlunya membangun kemandirian ekonomi, perlunya mencintai hasil produksi dalam negeri maupun praduk lokal dan lain-lain. Materi ajar Bahasa Indonesia dapat mengarahkan kesadaran anak tentang kearifan lokal melalui pelajaran mengarang, membuat puisi ataupun membuat peribahasa dengan tema-tema lokal. Demikian pula pada IPA, IPS, Seni Budaya dan Ketrampilan, Pendidikan kesehatan, berbagai materi ajar dasar maupun pengembangan diri. 


\section{DAFTAR PUSTAKA}

Abdullah, Irwan, 2009, Konstruksi dan Reproduksi Kebudayaan (Yogyakarta: Pustaka Pelajar, Cet. III).

Anna Sri Marlupi, Pendidikan Berbasis Kearifan Lokal, dalam http://www.pangudiluhur.org/berita/pendidikanberbasis-kearifan-lokal-oleh-anna-sri-marlupi-ss.104.html (Akses pada 17 Oktober 2014).

Akhsan Sukroni, Pendidikan Karakter Berbasis Kearifan Lokal, dalam

http://www.unmabanten.ac.id/index.php/kumpulanartikel-opini/140-pendidikan-karakter-berbasiskearifan-lokal (Akses pada 17 Oktober 2014).

Blum, Lawrence A., 2001, Antirasisme, Multikulturalisme, dan Komunitas Antar-Ras (Yogyakarta: Tiara Wacana).

Dinar Pratama, dalam http://bangka.tribunnews.com/2014/ 05/21/opini-pendidikan-karakter-berbasis-kearifanlokal (Akses pada 17 Oktober 2014).

Direktorat Jenderal Kesatuan Bangsa dan Politik Departemen Dalam Negeri, 2007, Peraturan Menteri dalam Negeri Nomor 39 Tahun 2007 tentang Pedoman Fasilitasi Organisasi Kemasyarakatan Bidang Kebudayaan, Keraton, dan Lembaga Adat dalam Pelestarian dan Pengembangan Budaya Daerah.

Eri Irawan, dalam http://researchengines.educationcreativity. com/ 0106eri.html (Akses 17 Oktober 2014).

Haris, Abd., 2010, Strategi Pengembangan Perguruan Tinggi Islam Berbasis Kearifan Lokal di Tengah Tantangan Globalisasi, Makalah tidak Publikasi.

http://sosbud.kompasiana.com/2013/12/17/pendidikankarakter-berbasis-kearifan-budaya-lokal-619934.html (Akses 17 Oktober 2014). 
Nadlir

Khasan Ubaidillah, "Integrasi Kearifan Lokal dalam Pendidikan Karakter", dalam http://qudsiyyah.com/2013/12/ integrasi-kearifan-lokal-dalam-pendidikan-karakter/ (Akses 17 Oktober 2014).

Majalah El-Qudsy, Edisi 21 tahun 2013.

Palmer, J. Parker, 2009, Keberanian Mengajar (Jakarta: Permata Puri Media).

Setiawan, Benni, 2008, Agenda Pendidikan Nasional (Yokyakarta: Ar-Ruz Media Group).

Tobroni, Relasi Kemanusiaan dalam Keagamaan (Mengembangka Etika Sosial Melalui Pendidikan) (Bandung: CV. Karya Putra Darwati, 2012).

Widjajaputra, Bima, 2008, "Penyelenggaraan Pendidikan Berbasis Kearifan Lokal dan Hak-hak Anak", dalam Rambu-Rambu Pelaksanaan Pendidikan Berbasis Kearifan Lokal dan HakHak Anak (Bantul: SD Sendangsari). 